УДК 343.13

DOI https://doi.org/10.32849/2663-5313/2019.5.55

\title{
Сергій Шульгін,
}

аспірант кафедри кримінального права та правосуддя

Міжнародного економіко-гуманітарного університету імені академіка Степана Дем'янука

\section{ПОНЯТТЯ ОБГРУНТОВАНОСТІ ПІДОЗРИ В КРИМІНАЛЬНОМУ ПРОВАДЖЕННІ}

Стаття присвячена поняттю обгрунтованості підозри в кримінальному провадженні, зокрема, у контексті обгрунтованості повідомлення про підозру як прочесуального рішення та підстави застосування заходів забезпечення кримінального провадження. Проведено аналіз начіонального законодавства, практики Європейського суду з прав людини й начіональних судів з досліджуваної проблеми, а також сформульовано власні висновки та пропозииії, спрямовані на вдосконалення кримінального процесуального законодавства щодо цього питання.

Ключові слова: обгрунтована підозра, повідомлення про підозру, процесуальне рішення слідчого/ прокурора, заходи забезпечення кримінального провадження, запобіжний захід.

Постановка проблеми. Запровадження в Кримінальному процесуальному кодексі України (далі - КПК України) правових понять, які використовуються в законодавстві Європейських країн, яскраво свідчить про подальший демократичний і правовий шлях розвитку Українського законодавства. Так, прийняттям 13.04.2012 Верховною Радою України нового Кримінального процесуального закону у сферу кримінального судочинства введено поняття «обгрунтована підозра», наявність якої пов'язано, як правило, із застосуванням заходів забезпечення кримінального провадження (п. 1 ч. 3 ст. 132, п. 3, ч. 2 ст. 173 КПК України), зокрема запобіжних заходів, у тому числі зміни або доповнення клопотання про застосування запобіжного заходу (ч. 2 ст. 177, ч. 1 ст. 185 , п. 1 ч. 1 ст. 194 КПК України) та надавання дозволу на затримання з метою приводу (п. 4 ст. 1 ст. 190 КПК України).

Однак, як показала практика застосування положень КПК України, існує багато недоліків, які, незважаючи на демократичність їх походження, потребують подальшого наукового дослідження, а з огляду на їх актуальність, і якнайшвидшого втілення у сферу правового регулювання.

Проблемам обгрунтованості підозри присвячені наукові праці М.С. Громової, А.Я. Дубінського, Л.П. Ісмакаєва, О.В. Капліної, Ю.В. Манаєва, Х.Р. Слюсарчук, С.А. Шейфера. Однак у своїй більшості їхні праці зводились до з'ясування правової природи обгрунтованості підозри, аналізу норм національного законодавства та практики Європейського суду з прав людини (далі - ЄСПЛ) з приводу тлумачення вказаного поняття. Разом із тим поза межами їніх наукових досліджень залишились такі актуальні проблеми, як правові наслідки визнання підозри не обгрунтованою, чи має значення таке рішення в разі проведення нових слідчих (розшукових) дій, у ході яких будуть здобуті нові докази на підтвердження обгрунтованості підозри та повторного звернення до суду з аналогічним клопотанням, а також яке значення матиме визнання підозри необгрунтованою для суду, який розглядатиме обвинувальний акт по суті.

Метою статті є аналіз наукових робіт щодо проблем обгрунтованості підозри, аналіз національного законодавства та позицій ЄСПЛ із цього приводу, вивчення практики їх застосування, зокрема, слідчими суддями під час розгляду клопотань про обрання запобіжного заходу, виявлення недоліків правого регулювання й висловлення пропозицій, спрямованих на їх усунення. При цьому ще більшої актуальності набуло з'ясування значення обгрунтованої підозри з огляду на запровадження в КПК України можливості їі оскарження на досудовому розслідуванні.

Виклад основного матеріалу. У національному законодавстві визначення обгрунтованості підозри відсутнє. Закон також не передбачає необхідну сукупність (кількість) доказів, за яких підозру можна визнати обгрунтованою, що вказує на оцінний характер указаного поняття й залишення законодавцем його визначення в кожній конкретній ситуації на розсуд правозастосувача.

У роботі ми спробуємо з'ясувати сутність поняття «обгрунтована підозра» в контексті його застосування до повідомлення 
про підозру як процесуального рішення, а також клопотання про застосування запобіжного заходу.

Передусім приєднуємось до позиції науковців, які визначають повідомлення про підозру як процесуальне рішення. Так, на думку В.О. Гринюк, підозра - це процесуальне рішення прокурора, слідчого (за погодженням із прокурором), яке грунтується на зібраних доказах під час досудового розслідування та в якому формується припущення про причетність конкретної особи до вчинення кримінального правопорушення з повідомленням про це такій особі й із роз'ясненням іï прав та обов'язків [1, с. 36-37]. А.І. Палюх повідомлення про підозру вважає одним із важливих процесуальних рішень під час здійснення кримінального провадження в стадії досудового розслідування [2, с. 112]. При цьому, зазначає науковець, повідомлення особі про підозру в теорії кримінального процесу може тлумачитись як важливе процесуальне рішення, яке приймає прокурор або слідчий за погодженням із прокурором; як процесуальна дія; як інститут кримінального процесуального права; як форма повідомлення в кримінальному провадженні; як процесуальний акт [2, с. 114-115]. Н.П. Черняк повідомленням особи про підозру називає одним із важливих процесуальних рішень, яке приймає прокурор або слідчий за погодженням із прокурором до закінчення розслідування в кримінальному провадженні. У цьому процесуальному рішенні на основі доказів, зібраних у ході проведення досудового розслідування, конкретна особа набуває статусу підозрюваного [3, с. 556]. Г.І. Івасюк під повідомленням про підозру розуміє кримінальне процесуальне рішення слідчого, прокурора, яке приймається в обов'язковому порядку у випадках затримання особи за підозрою в учиненні кримінального правопорушення або наявності достатніх доказів для підозри особи в учиненні кримінального правопорушення в письмовій формі й тягне за собою набуття особою, щодо якої воно прийняте, процесуального статусу підозрюваного [4, с. 77]. Слушною є думка Ю.П. Аленіна та I.В. Гловюк, які зазначають, що формально повідомлення про підозру в аспекті назви дійсно не відповідає ч. 3 ст. 110 КПК України, однак, з іншого боку, воно повністю відповідає ознакам кримінально-процесуальних рішень, що дає змогу його розглядати саме в такому аспекті [5, с. 162]. 3 огляду на викладене, приєднуємося до висловленої цими науковцями думки, що в КПК України варто внести зміни, якими процесуальне рішення у вигляді повідомлення про підозру потрібно замінити на постанову [5, с. 166].
Не вдаючись до ретельного аналізу повідомлення про підозру як процесуального рішення, що може бути об'єктом іншого наукового дослідження, більше зупинимось на з'ясуванні обгрунтованості підозри як процесуального рішення, а також похідної від нього обгрунтованої підозри як підстави застосування запобіжного заходу до підозрюваного.

Згідно 3 п. 3 ч. 1 ст. 276 КПК України, повідомлення про підозру обов'язково здійснюється в порядку, передбаченому статтею 278 цього Кодексу, у випадках, зокрема, наявності достатніх доказів для підозри особи в учиненні кримінального правопорушення. 3 огляду на викладене, варто погодитися з думкою M.Є. Громової, яка пише, що КПК України не висуває до письмового повідомлення про підозру окремо такої вимоги, як обгрунтованість [6, с. 41]. При цьому, досліджуючи обгрунтованість підозри, вчена зазначає таке: обгрунтованою є підозра за наявності таких принципових обставин: 1) врученого письмового повідомлення про підозру з обов'язковим посиланням на докази вчинення особою кримінального правопорушення; 2) наявності в матеріалах кримінального провадження доказів, що підтверджують учинення особою кримінального правопорушення; 3) доведення перед судом вагомості й достатності наявних доказів про вчинення особою кримінального правопорушення; 4) оцінювання судом доказів учинення особою кримінального правопорушення [6, с. 43].

Як із цього приводу зазначає А.Я. Дубінський, указівка на достатність доказів як підставу для прийняття окремих рішень (про притягнення особи до кримінальної відповідальності) міститься безпосередньо в законі. 3 приводу більшості процесуальних рішень такої прямої вказівки закон не містить, однак і ці рішення повинні бути обгрунтованими, тобто спиратись на достатні докази, які не лишають сумніву в правильності зробленого висновку [7, с. 16]. Отже, вимога достатності доказів до моменту притягнення особи до кримінальної відповідальності означає, що в розпорядженні слідчого повинна бути така сукупність доказів, яка, будучи неповною, приводить тим не менше до обгрунтованого висновку про винуватість особи, котра притягується, і виключає в цей момент розслідування протилежного висновку [7, с. 106].

Слушну думку, яка заслуговує на підтримку, висловила О.В. Капліна, зазначивши, що підозра повинна бути обгрунтованою, оскільки закон вимагає, що особа обов'язково повідомляється про підозру передусім за наявності достатніх доказів для її підозри в учиненні кримінального правопорушення 
(п. 3 ч. 1 ст. 276 КПК України). Якщо про підозру повідомляється особа в разі обрання щодо неї запобіжного заходу, у клопотанні слідчого також уже мають бути такі достатні докази, оскільки КПК України встановлює, що підставою для застосування запобіжного заходу є наявність обгрунтованої підозри в учиненні особою кримінального правопорушення (ч. 2 ст. 177 КПК України). Підставою для ймовірного висновку про причетність особи до вчинення злочину та повідомлення особи про підозру є також сам собою факт затримання особи на місці вчинення кримінального правопорушення чи безпосередньо після його вчинення (п. 1 ч. 1 ст. 276 КПК України). Цим фактом й обгрунтовується виникнення припущення про вчинення кримінального правопорушення певною особою [9, c. 241].

Вдалим до досліджуваної проблеми є підхід А.І. Палюхи, який пише, що відсутність у главі 22 КПК вимоги про обгрунтоване повідомлення особі про підозру не відповідає положенню, що доказів для повідомлення про підозру буде достатньо тоді, коли вони у своїй сукупності підтверджують винність особи й виключають будь-яке припущення про винного стосовно когось іншого до розслідуваного діяння. Таке формулювання «доказів не повинно бути ні багато, ні мало, а саме достатньо» потребує виключення всякого іншого тлумачення про винність особи, яка підлягає притягненню до кримінальної відповідальності [10, с. 482]. При цьому науковець указує, що для обгрунтованого повідомлення про підозру повинна бути зібрана достатня сукупність доказів, яка достовірно встановлює ті обставини, з-поміж яких підлягають доказуванню в кримінальному провадженні ті, без яких не можна визначити склад злочину, висунути підозру певній особі, винній у його вчиненні $[10$, с. 480].

Як правильно зазначає із цього приводу Ю.В. Манаєв, до моменту притягнення особи до кримінальної відповідальності слідчий повинен установити обставини, які входять до предмета доказування в кримінальній справі в такому об'ємі, щоб їх було достатньо для висновку про наявність конкретного злочину і його кваліфікації згідно 3 кримінальним законом. Для цього необхідно встановити й відобразити у відповідному процесуальному рішенні об'єктивні та суб'єктивні ознаки злочину. Законність та обгрунтованість акта про притягнення особи до кримінальної відповідальності необхідна в усіх випадках для правильної кримінальноправової оцінки вчиненого особою злочину. Вимога законності й обгрунтованості притягнення до кримінальної відповідальності не звільняє слідчого від подальшої перевірки висунутих обвинуваченим версій про відсутність події злочину, про його невинуватість. У процесі подальшого провадження по справі обставини злочину можуть уточнюватись і доповнюватись, також вони можуть бути повністю спростованими [11, с. 87].

Разом із тим, незважаючи на відсутність у законі вимоги про обгрунтованість підозри як процесуального рішення, на це вказує комплексний аналіз положень кримінального-процесуального закону, зокрема, як вище зазначалось, згідно 3 п. 3 ч. 1 ст. 276, повідомлення про підозру обов'язково здійснюється за наявності достатніх доказів для підозри особи в учиненні кримінального правопорушення. У разі обрання запобіжного заходу ч. 2 ст. 177 і п. 1 ч. 1 ст. 194 КПК України зобов'язують слідчого суддю перевірити наявність обгрунтованої підозри в учиненні підозрюваним, обвинуваченим кримінального правопорушення. Наведене свідчить, що обгрунтованість підозри передусім повинна випливати зі змісту процесуального рішення повідомлення про підозру.

На практиці для з'ясування сутності обгрунтованості підозри набуло поширення застосування рішень ЄСПЛ, у яких міститься роз'яснення вказаного поняття, зокрема в рішеннях «Фокс, Кембел і Хартлі проти Сполученого Королівства» від 30.08.1990 [12], «Лабіта проти Італії» від 06.04.2000 [13], «Мюррей проти Сполученого Королівства» від 28.10.1994 [14] і «Нечипорук і Йонкало проти України» від 21.04.2011 [15] зазначено, що наявність «обгрунтованої підозри» передбачає існування фактів та інформації, які могли б переконати об'єктивного спостерігача в тому, що ця особа могла вчинити злочин, хоча те, що може розглядатись як «обгрунтоване», залежить від усіх цих обставин. Аналогічного підходу дотримався ЄСПЛ у справі «К.-Ф. Проти Німеччини» від 27.11.1997, додавши, що факти, які породжують підозру, не обов'язково мають такий саме рівень з'ясовності, який потребується на пізнішому етапі кримінального розслідування [16].

Наведене свідчить, що обгрунтованість підозри не може бути незмінною (статичною). У ході проведення судового розслідування проводяться слідчі (розшукові) дії, в результаті проведення яких зібрані докази або спростовують обгрунтованість підозри, або, навпаки, її посилюють.

Аналогічної точки зору дотримується Х.P. Слюсарчук, яка пише, що обгрунтована підозра не є «статичною» категорією, а, навпаки, вона наділена «динамічним» триваючим характером. Так, наприклад, після 
встановлення наявності обгрунтованої підозри як підстави для застосування запобіжного заходу в кримінальному провадженні «обгрунтованість» такої підозри під час безпосереднього застосування запобіжного заходу повинна продовжувати не лише існувати, але й збільшуватись за рівнем обгрунтованості. Ступінь обгрунтованості підозри, який став підставою для обрання запобіжного заходу, наприклад, тримання під вартою, не може бути прийнятним для вирішення питання про продовження строків тримання під вартою. Стандарт доказування «обгрунтована підозра» є багаторівневою категорією, оскільки під час кримінального провадження «обгрунтована підозра» повинна збільшуватись за рівнем «обгрунтованості» припущення про вчинення кримінального правопорушення конкретною особою [17, с. 11].

Щодо зменшення рівня обгрунтованості підозри слушною є думка Ю.В. Манаєва, який указує, що зміна та скасування обвинувачення ні в якому разі не свідчать про порушення принципу законності й обгрунтованості діяльності слідчого під час притягнення особи до кримінальної відповідальності. З'ясування нових обставин і у зв'язку 3 цим нового обвинувачення в процесі розслідування є лише свідчення активної діяльності слідчого щодо виконання поставлених перед ним завдань [11, с. 87]. Такий підхід повністю узгоджується із завданнями кримінального провадження, визначеними в ст. 2 КПК України.

Згідно з п. 10 ч. 1 ст. 303 КПК України, на досудовому провадженні можуть бути оскаржені, зокрема, повідомлення слідчого, прокурора про підозру після спливу одного місяця 3 дня повідомлення особі про підозру в учиненні кримінального проступку або двох місяців з дня повідомлення особі про підозру в учиненні злочину, але не пізніше закриття прокурором кримінального провадження або звернення до суду з обвинувальним актом.

Разом із тим у законі відсутній перелік підстав для скасування повідомлення про підозру. Проведений нами аналіз судової практики, зокрема ухвал слідчих суддів, розміщених у Єдиному державному реєстрі судових рішень, якими скасовано повідомлення про підозру, дає підстави виділити 3 види підстав для касування повідомлень про підозру, а саме:

- н неналежний суб'єкт складення та вручення повідомлення про підозру;

- порушення процесуального порядку вручення повідомлення про підозру;

- необгрунтованість підозри.

Варто відмітити, що приблизно такого ж підходу дотримався слідчий суддя Борис- пільського міськрайонного суду Київської області, який ухвалою від 27.12.2018 (справа № 359/10654/18), скасовуючи повідомлення про підозру щодо ОСОБА_2, зазначив, що питання стосовно наявності підстав для скасування повідомлення про підозру слідчим суддею вирішується у світлі встановлення судом порушення порядку повідомлення про підозру або встановлення фактів затягування правоохоронними органами досудового розслідування після оголошення певній особі про підозру, тобто для недопущення довготривалої невизначеності статусу особи щодо вчинення або невчинення нею злочину, тобто задля недопущення тривалого перебування особи в статусі підозрюваного без вироку суду із цього питання. Також слідчий суддя в указаній ухвалі зазначив, що системний аналіз положень ст. ст. 276-278 КПК України вказує на те, що в разі розгляду скарги на рішення слідчого про підозру слідчий суддя має з'ясувати виконання слідчим положень кримінального процесуального закону в частині дотримання порядку повідомлення про підозру та наявності на день повідомлення про підозру достатніх доказів для підозри особи [18].

Спробуємо здійснити більш детальний аналіз цих підстав. Так, відповідно до п. 1 ст. 277 КПК України, письмове повідомлення про підозру складається прокурором або слідчим за погодженням із прокурором. Частиною 1 ст. 278 цього Кодексу передбачено, що письмове повідомлення про підозру вручається в день його складення слідчим або прокурором. Наведене свідчить, що виключно прокурор або слідчий за погодженням із прокурором можуть скласти письмове повідомлення про підозру та здійснити його вручення. Будь-яких винятків із цього приводу закон не передбачає.

Відповідно до ч. 1 ст. 42 КПК України, підозрюваною є особа, якій у порядку, передбаченому ст. ст. 276-279 цього Кодексу, повідомлено про підозру. Тобто не тільки порушення, допущені під час складання, а й під час вручення повідомлення про підозру, не породжують правових наслідків у вигляді набуття особою статусу підозрюваного, а тому є підставою для її скасування. Аналогічного підходу дотримується й судова практика. Зокрема, ухвалою слідчого судді Херсонського міського суду Херсонської області від 25.07.2018 (справа № 766/7144/18), якою скасовано повідомлення про підозру щодо ОСОБА_3, встановлено, що 3 матеріалів скарги та доданого до неї витягу з СРДР від 14.04.2018 і повідомлення про початок досудового розслідування від 13.04.2018 слідчим по цьому кримінальному провадженню зазна- 
чений ОСОБА_12, але, як убачається з матеріалів скарги, повідомлення про підозру винесено та підписано слідчим ОСОБА_14, але жодного процесуального документа до суду не надано, що слідчий ОСОБА_14 є в групі слідчих, які мають процесуальне право здійснювати будь-які слідчі (розшукові) дії [19].

Аналіз указаної ухали слідчого судді свідчить про те, що підставою для ії̈ скасування стало складання повідомлення про підозру неналежним суб'єктом - слідчим, якому не доручено здійснення досудового розслідування в цьому кримінальному провадженні.

Слідчий суддя Орджонікідзевського районного суду м. Харкова ухвалою від 30.05.2016 (справа № 644/4479/16-к), зобов'язуючи уповноваженого прокурора в кримінальному провадженні вчинити дії, визначені п. 1 ч. 2 ст. 283, п. 2 ч. 1 ст. 284 КПК України (закрити кримінальне провадження) щодо ОСОБА 2, у мотивувальній частині ухвали вказав, що з матеріалів кримінального провадження, а саме $з$ рапорту ст. о/у в ОВС УПЗСЕ ГУМВС України в Харківській області, адресованого слідчому, з приводу вручення повідомлення про підозру ОСОБА_2, а також установлення місця знаходження ОСОБА_2, вручення повідомлення про підозру для передачі ОСОБА_2 представнику КП «Жилкомсервіс» вйливає, що вказані процесуальні дії здійснювались співробітником оперативного підрозділу. Зазначене свідчить про те, що вручення повідомлення про підозру відбувалось не в передбачений КПК України спосіб не уповноваженою на те особою, тобто застосовано неналежну правову процедуру [20].

Наведене свідчить, що передоручення вручення повідомлення про підозру іншій, не уповноваженій на це законом особі є порушенням процесуального закону й тягне відповідні правові наслідки у вигляді підстави для скасування повідомлення про підозру. При цьому варто відмітити, що передоручення вручення повідомлення про підозру не допускається не лише працівникові оперативного підрозділу, а й слідчому чи прокурору.

Так, в ухвалі слідчого судді Зарічного районного суду м. Суми від 09.08.2017 (справа № 591/2880/17), якою скасовано повідомлення про підозру щодо ОСОБА_2, зазначено, що прокурор Сумської області склав письмове повідомлення про підозру в кримінальному провадженні, що зазначене вище. У вказаному повідомленні вказано, що її вручення доручено старшому слідчому слідчого відділу управління з розслідування кримінальних проваджень слідчим органів прокуратури та процесуального керівництва прокуратури Сумської області або начальнику першого відділу процесуального керівництва у кримінальних провадженнях вказаного управління прокуратури Сумської області, тобто прокурор передоручив ці повноваження слідчим та іншим працівникам правоохоронних органів повноваження в порядку ст. 36 КПК України. Слідчий суддя не може погодитися з такими процесуальними діями прокурора, адже законом визначено вичерпний перелік суб'єктів, які мають право повідомити окремій категорії осіб про підозру, тобто здійснити всі процесуальні дії, внаслідок яких особа набуде статусу підозрюваного, - скласти повідомлення та вручити його, а тому передоручення повноважень на здійснення одного зі складників цієї процедури є, на думку слідчого судді, неправильним. Тобто частина однієї процесуальної дії не може виконуватися [21].

Наведене в указаній ухвалі слідчого судді порушення у вигляді передоручення вручити повідомлення про підозру слідчому або іншому прокурору (належний суб'єкт вручення повідомлення про підозру) стало підставою для її скасування.

Такої самої позиції дотримується й Верховний Суд, який Постановою від 19.02.2019 (справа № 349/1487/14-к), залишаючи в силі ухвалу Апеляційного суду Волинської області про закриття кримінального провадження на підставі п. 3 ч. 1 ст. 284 КПК України, зазначив, що, відповідно до ч. 4 ст. 49 Закону України «Про судоустрій і статус суддів», п. 3 ч. 1 ст. 481 КПК, України повідомлення судді про підозру здійснюється лише Генеральним прокурором або його заступником.

За змістом ст. 276 КПК України, процедура здійснення повідомлення про підозру включає в себе складання письмового повідомлення про підозру й, відповідно, його вручення підозрюваному уповноваженою особою.

Отже, якщо в учиненні злочину підозрюється особа, щодо якої, згідно з приписами ст. 480 КПК України, передбачено здійснення особливого порядку кримінального провадження, письмове повідомлення про підозру такій особі повинно бути вручене безпосередньо посадовими особами органів прокуратури, визначеними в п. п. 1-4 ч. 1 ст. 481 КПК України, і здійснення такої дії не може бути передоручене.

Водночас, як убачається з матеріалів кримінального провадження, письмове повідомлення про підозру судді ОСОБА_2 хоча й було складено першим заступником Генерального прокурора України, проте вручене особою, яка за посадою не є Генеральним прокурором або його заступником, чим істот- 
но порушено вимоги процесуального закону в частині процедури притягнення особи до кримінальної відповідальності [22].

Наступною, на нашу думку, підставою для скасування повідомлення про підозру є іï необгрунтованість. При цьому на проблему обгрунтованості підозри варто звернути особливу увагу, оскільки її відсутність є підставою для скасування повідомлення про підозру, а також, відповідно до ч. 2 ст. 194 КПК України, підставою для відмови в застосуванні запобіжного заходу.

3 приводу необгрунтованості повідомлення про підозру як підстави для їі скасування в Україні вже починає формуватись відповідна судова практика. Так, скасовуючи повідомлення про підозру щодо ОСОБА_2 через іiі необгрунтованість, слідчий суддя Зарічного районного суду м. Суми в ухвалі від 06.09.2018 (справа № 591/4134/18) зазначив, що на момент повідомлення ОСОБА_2 про підозру варто констатувати те, що в кримінальному провадженні № 42018200000000103 від 02.05.2018 підозра не досягла потрібного рівня обгрунтованості, оскільки вона не грунтувалася на конкретних фактах і відомостях, що об'єктивно пов’язували б ОСОБА_2 з учиненням кримінального правопорушення, передбаченого ч. 5 ст. 27 , ч. 3 ст. 368 Кримінального кодексу (далі - КК) України, і в слідчого, який складав повідомлення про підозру ОСОБА_2, не було доказів, що б указували на причетність останнього до вчинення саме вказаного в підозрі кримінального правопорушення. Усі вищезазначені обставини дають підстави стверджувати, що підозра, оголошена ОСОБА_2 від 15.06.2018, у вчиненні кримінального правопорушення, передбаченого ч. 5 ст. 27, ч. 3 ст. 368 КК України, по кримінальному провадженню № 42018200000000103 від 02.05.2018 не є обгрунтованою, а тому наявні підстави для її скасування [23].

В ухвалі від 28.12.2018 (справа № 564/3469/18) слідчий суддя Костопільського районного суду Рівненської області, скасовуючи повідомлення про підозру щодо ОСОБА_1, з аналогічних підстав зазначив, що обставини кримінального правопорушення та здобуті досудовим розслідуванням докази свідчать про очевидну необгрунтованість підозри й неправильну правову кваліфікацію вчиненого злочину [24].

Розглядаючи апеляційні скарги прокурора та підозрюваного ОСОБА_4 на ухвалу слідчого судді Світловодського міськрайонного суду Кіровоградської області про застосування стосовно останнього запобіжного заходу, Кропивницький апеляційний суд ухвалою від 03.01.2019 (провадження № 11-cс/4809/6/19), визнавши необгрунтованою підозру щодо підозрюваного, зазначив, що, на думку колегії суддів, покази, надані в судовому засіданні потерпілим, спростовують обгрунтованість підозри, висунутої ОСОБА_4, а письмові докази навіть у своїй сукупності не дають достатніх підстав уважати, що ОСОБА 4 міг учинити злочин, передбачений ч. 2 ст. 289 КК України, а тому слідчий суддя зобов'язаний був постановити ухвалу про відмову в застосуванні запобіжного заходу, оскільки під час розгляду клопотання прокурором не доведено наявність усіх обставин, передбачених ч. 1 ст. 194 КПК України.

Доводи підозрюваного та його захисника щодо відсутності обгрунтованої підозри в учиненні кримінального правопорушення колегія суддів вважає слушними, оскільки перевіркою матеріалів клопотання слідчого встановлено, що надані органом досудового розслідування письмові докази в обгрунтування підозри, висунутої ОСОБА_4, не доводять повною мірою їі «обгрунтованість» у розумінні достатності «поза розумним сумнівом» уважати, що особа вчинила або причетна до вчинення злочину [25].

Разом із тим у кримінальному процесуальному законі відсутня вказівка на правові наслідки визнання повідомлення про підозру необгрунтованою (окрім як відмови в застосуванні запобіжного заходу щодо особи), а також у разі скасування повідомлення про підозру.

Так, не зрозумілим залишається, чи може слідчий проводити слідчі (розшукові) дії, спрямовані на доведення винуватості особи, щодо якої повідомлення про підозру визнано не обгрунтованим, чи повинен прокурор закрити кримінальне провадження, яке має значення для суду, який здійснює розгляд обвинувального акта в такому кримінальному провадженні, тощо.

Так, відповідно до ч. 1 ст. 198 КПК України, висловлені в ухвалі слідчого судді, суду за результатами розгляду клопотання про застосування запобіжного заходу висновки щодо будь-яких обставин, які стосуються суті підозри, обвинувачення, не мають преюдиціального значення для суду під час судового розгляду або для слідчого чи прокурора під час цього або іншого кримінального проваджень. Наведене дає підстави зробити висновок, що в разі визнання підозри необгрунтованою слідчий суддя тільки відмовляе в застосуванні до особи запобіжного заходу.

Також закон не визначає, як діяти слідчому судді в разі повідомлення про підозру особи в учиненні кількох кримінальних правопорушень, де для доведення обгрунтованості одного $з$ них недостатньо доказів, які б указу- 
вали на обгрунтованість. За таких обставин уважаємо, слідчий суддя повинен у мотивувальній частині ухвали вказати, з яких міркувань частину підозри він визнає необгрунтованою, а за наявності до того підстав обрати запобіжний захід за іншими інкримінованими кримінальними правопорушеннями.

Подібний підхід застосував Апеляційний суд м. Києва, який ухвалою від 15.03.2017 (справа № 11-сc/796/142/2017) скасував ухвалу слідчого судді Печерського районного суду м. Києва, якою продовжено строк тримання під вартою щодо ОСОБА 6 за підозрою в учиненні кримінальних правопорушень, передбачених ч. 3 ст. 27, ч. 5 ст. 191; ч. 3 ст. 110; ч. 1 ст. 258-3 КК України, і постановив нову ухвалу, якою продовжив строки тримання під вартою щодо ОСОБА 6, який обгрунтовано підозрюється тільки в учиненні кримінальних правопорушень, передбачених ч. 3 ст. 110, ч. 1 ст. 258-3 КК України. При цьому підозру в частині кваліфікації дій ОСОБА 6 за ч. 5 ст. 191 КК України суд визнав необггрунтованою [26].

Уважаємо, що визнання підозри необгрунтованою під час розгляду клопотання про застосування запобіжного заходу або його продовження не перешкоджає подальшому проведенню досудового розслідування, оскільки за таких умов особа не припиняе мати процесуальний статус підозрюваного. Проводячи досудове розслідування, слідчий і прокурор можуть здобути додаткові докази, які з більшим ступенем переконливості свідчитимуть про обгрунтованість підозри особи в інкримінованому кримінальному провадженні. У разі ж, навпаки, підтвердження необгрунтованості підозри та вичерпання можливостей отримання доказів винуватості особи прокурор повинен закрити кримінальне провадження.

Якщо ситуація 3 правовими наслідками визнання підозри необгрунтованою під час розгляду клопотання про застосування запобіжного заходу особливих труднощів на практиці не викликає, то зовсім протилежна ситуація зі скасуванням повідомлення про підозру через іiї необгрунтованість. Нічого також у законі не сказано про наслідки щодо допустимості доказів, отриманих під час проведення слідчих дій з підозрюваним, щодо якого повідомлення про підозру скасовано, а також їх подальшого використання щодо цієї або інших осіб. Не врегульовано порядок скасування заходів забезпечення кримінального провадження щодо такої особи (запобіжного заходу, арешту майна, відсторонення від посади тощо)

Уважаємо, що докази, отримані під час проведення слідчих (розшукових) дій за участі особи, щодо якої скасовано повідомлення про підозру, є допустимими за умови дотримання вимог законодавства під час ïx проведення. Такий підхід узгоджується 3 приписами ч. 1 ст. 86 КПК України.

Так, після скасування повідомлення про підозру особа втрачає статус підозрюваного, що автоматично позбавляє права застосовувати до такої особи заходи процесуального примусу.

Отже, вважаємо, що ухвала слідчого судді, якою скасовано повідомлення про підозру, є підставою для скасування запобіжного заходу, відсторонення від посади, тимчасового обмеження в користуванні спеціальним правом, запобіжного заходу, арешту майна підозрюваного. У зв'язку з цим пропонуємо доповнити КПК України таким положенням, а також зазначити, що в разі скасування повідомлення про підозру слідчий суддя цією ж ухвалою може скасувати заходи забезпечення кримінального провадження, які були застосовані до особи.

Також уважаємо, що в разі скасування слідчим суддею повідомлення про підозру щодо особи незалежно від підстав для прийняття такого рішення прокурор повинен винести постанову про закриття кримінального провадження щодо такої особи.

\section{Висновки}

Проведений аналіз проблем поняття обгрунтованості підозри засвідчив недосконалість вітчизняного законодавства та складність його застосування на практиці. Відносна новизна запровадження механізму оскарження повідомлення про підозру й відсутність практики його застосування свідчать про необхідність подальшого його наукового дослідження.

Уважаємо, що запропонований нами підхід до усунення недоліків правового регулювання можна використати під час розроблення змін до КПК України, оскільки, на наш погляд, вони здатні усунути наявні законодавчі прогалини і спростити механізм їх практичного застосування.

\section{Список використаних джерел:}

1. Гринюк B.O. Спростування стороною захисту підозри (первинного обвинувачення) під час досудового розслідування. Вісник кримінального судочинства. 2015. № 3. С. 34-39.

2. Палюх А.І. Участь прокурора в доказуванні під час досудового розслідування: дис. ... канд. юрид. наук: спец. 12.00.09. Львів, 2016. 206 с.

3. Черняк Н.П. Процесуальні особливості повідомлення особі про підозру. Науковий вісник Дніпропетровського державного університету внутрішніх справ. 2013. № 1. С. 555-561. 
4. Івасюк I.Г. Інститут «повідомлення про підозру» нового кримінального процесуального законодавства України. Митна справа. 2013. № 4 (2.2). С. $74-79$.

5. Аленін Ю.П., Гловюк І.В. Повідомлення про підозру: загальна характеристика та проблеми удосконалення. Вісник Південного регіонального иентру Національної академії правових наук України. 2014. № 1. С. 161-169.

6. Громова М.Є. Обгрунтована підозра як підстава застосування запобіжних заходів. Часопис Академї адвокатури Украӥни. 2015. Т. 8. № 2. C. $40-43$.

7. Дубинский А.Я. Правовые и организационные проблемы исполнения процессуальных решений следователя: автореф. дисс. ... докт. юрид. наук. Киев, 1984. 46 с.

8. Исмакаев Л.П., Шейфер С.А. Пределы доказывания и обоснованность процессуальных решений следователя. Актуальные вопросы реализации уголовной ответственности: межвузовский сборник статей. Куйбышев: Изд-во Куйбышев. ун-та, 1988. С. 100-112.

9. Капліна О.В. Підозра у кримінальному провадженні: поняття, ознаки, сутність. Юридичний часопис Національної академї внутрішніх справ. 2013. № 1. C. 238-242.

10. Палюх А.І. Участь прокурора в доказуванні при повідомленні про підозру під час досудового розслідування. Вісник Національного університету «Львівська політехніка». Серія «Юридичні науки». 2016. № 837. С. 476-483.

11. Манаев Ю.В. Обоснованность процессуальных решений следователя. Советское государство и право. Москва: Наука, 1978. № 5. С. 84-88.

12. Фокс, Кембелл і Хартлі проти Сполученого Королівства: Рішення Свропейського суду 3 прав людини (заяви № 12244/86; 12245/86; 12383/86) від 30 серпня 1990 p. URL: http:// hudoc.echr.coe.int/sites/eng/pages/search.aspx?i= 001-57721 (дата звернення: 01.05.2019).

13. Лабіта проти Італії: Рішення Свропейського суду з прав людини (заява № 26772/95) від 6 квітня 2000 р. URL: http://hudoc.echr.coe.int/ sites/eng/pages/search.aspx?i=001-58559 ～(дата звернення: 01.05.2019).

14. Мюррей проти Сполученого Королівства: Рішення Європейського суду 3 прав людини (заява № 14310/88) від 28 жовтня 1994 p. URL: http://hudoc.echr.coe.int/sites/eng/pages/search. aspx?i=001-57895 (дата звернення: 01.05.2019).

15.Нечипорук і Йонкало проти України: Рішення Європейського суду 3 прав людини (заява № 42310/04) від 21 квітня 2011 р. URL https://zakon.rada.gov.ua/laws / show/ 974_683 (дата звернення: 01.05.2019).

16. К.-Ф. Проти Німеччини: Рішення Європейського суду з прав людини від 27 листопада 1997 p. URL: http://hudoc.echr.coe.int/sites/eng/ pages/search.aspx?i=001-58119 (дата звернення: 01.05.2019).

17. Слюсарчук Х.Р. Стандарти доказування у кримінальному провадженні: автореф. дис. ... канд. юрид. наук: спец. 12.00.09. Львів, 2017. 24 с.

18. Ухвала слідчого судді Бориспільського міськрайонного суду Київської області від 27.12.2018 (справа № 359/10654/18). URL: http://www.reyestr.court.gov.ua/Review / 78988292 (дата звернення: 01.05.2019).

19. Ухвала слідчого судді Херсонського міського суду Херсонської області від 25.07.2018 (справа № 766/7144/18). URL: http:// www.reyestr.court.gov.ua/Review/75577285 (дата звернення: 01.05.2019).

20. Ухвала слідчого судді Орджонікідзевського районного суду м. Харкова від 30.05.2016 (справа № 644/4479/16-к). URL: http:// www.reyestr.court.gov.ua/Review/58032156 (дата звернення: 01.05.2019).

21. Ухвала слідчого судді Зарічного районного суду м. Суми від 09.08.2017 (справа № 591/2880/17). URL: http:// www.reyestr.court.gov.ua/Review/68194346 (дата звернення: 01.05.2019).

22. Постанова Верховного Суду від 19.02.2019 (справа № 349/1487/14-к) URL http://reyestr.court.gov.ua/Review/80115441 (дата звернення: 01.05.2019).

23. Ухвала слідчого судді Зарічного районного суду м. Суми від 06.09.2018 (справа № 591/4134/18). URL: http://www.reyestr.court.gov. ua/Review/76372141 (дата звернення: 01.05.2019).

24. Ухвала слідчого судді Костопільського районного суду Рівненської області від 28.12.2018 (справа № 564/3469/18). URL: http:// www.reyestr.court.gov.ua/Review/78865188 (дата звернення: 01.05.2019).

25. Ухвала Кропивницького апеляційного суду від 03.01.2019 (провадження № 11-cc/4809/6/19). URL: http://www.reyestr. court.gov.ua/Review/79078716 (дата звернення: 01.05.2019).

26. Ухвала Апеляційного суду м. Києва від 15.03.2017 (справа № 11-сc/796/142/2017). URL: http://www.reyestr.court.gov.ua/Review/ 65469908 (дата звернення: 01.05.2019).

Статья посвящена понятию обоснованности подозрения в уголовном производстве, в частности, в контексте обоснованности сообщения о подозрении как процессуального решения и основания применения мер обеспечения уголовного производства. Проведен анализ нащионального законодательства, практики Европейского суда по правам человека и нащиональных судов по исследуемой проблеме, а также сформулированы собственные выводы и предложения, направленные на усовершенствование уголовного процессуального законодательства по этому вопросу.

Ключевые слова: обоснованное подозрение, сообщение о подозрении, процессуальное решение следователя/прокурора, меры обеспечения уголовного производства, мера пресечения. 
The article is devoted to the concept of the validity of suspicion in criminal proceedings, in particular in the context of the justification of the notification of suspicion as a procedural decision and the grounds for the application of measures to ensure criminal proceedings. The article analyzes the national legislation, the practice of the European Court of Human Rights and national courts on the problem under investigation, as well as formulates its own conclusions and proposals aimed at improving the criminal procedural legislation on this issue.

Key words: reasonable suspicion, suspicious notification, procedural decision of the investigator/ prosecutor, measures to ensure criminal proceedings, preventive measure. 